\title{
GENDER CONSTRUCTION IN UISUAL IMAGES IN TEXTBOOKS FOR PRIMARY SCHOOL STUDENTS
}

\author{
Ika Lestari Damayanti \\ Universitas Pendidikan Indonesia \\ email: ika.lestari.damayanti@gmail.com
}

\begin{abstract}
In the Indonesian context, little has been done to raise awareness of political correctness in gender matters in school textbooks. As an attempt to fill this gap, I conducted a textual analysis on four English language textbooks used in Indonesian primary schools. The focus of the study was on the pictorial texts accompanying the linguistic ones. The 'Visual Grammar', developed by Kress and van Leeuwen, was used as the framework of analysis. The results showed that the illustrations accompanying linguistic texts fortified the representations of gender asymmetry. Females were depicted more dependent than males and were also construed to be admirers of an action carried out by the males. The study recommended conscious efforts to value both genders equally in visualization as meaning construction is multimodal.
\end{abstract}

Keywords: gender construction, visual grammar, pictorial texts, EFL textbooks

\section{KONSTRUKSI GENDER DALAM CITRA VISUAL PADA BUKU TEKS UNTUK SISWA SEKOLAH DASAR}

\begin{abstract}
Abstrak:Di Indonesia, upaya penyadaran pentingnya isu penyetaraan gender dalam buku ajar sekolah masih belum banyak dilakukan. Untuk itu, penelitian ini dilakukan sebagai salah satu cara penyadaran isu gender dengan menginvestigasi representasi gender dalam buku ajar. Penelitian ini menggunakan analisis teks terhadap empat buku ajar yang digunakan di sekolah dasar. Fokus analisisnya adalah pada gambar ilustrasi yang menyertai teks tertulis seperti bagian bacaan. Gambar tersebut dianalisis dengan menggunakan teori 'Visual Grammar' yang dikembangkan oleh Kress dan van Leeuween. Hasilnya menunjukkan bahwa gambar-gambar tersebut merepresentasikan ketidaksetaraan gender. Perempuan digambarkan sebagai sosok yang tergantung pada orang lain dibandingkan laki-laki yang mandiri dan mereka berlaku sebagai pengagum pekerjaan yang dilakukan laki-laki. Berdasarkan hasil temuannya, penelitian ini merekomendasikan upaya yang lebih serius dalam menampilkan peran gender yang seimbang dan tidak hanya ditampilkan dalam teks tulis namun juga dalam gambar karena pada dasarnya makna dikonstruksi secara multimodal.
\end{abstract}

Katakunci:konstruksi gender, visual grammar, teks gambar.

In the Western context, the consciousness of political correctness in gender matters in school textbooks and teaching materials has been progressively endorsed since 
around the 1970s. Numerous studies have been conducted to raise this awareness and to rectify gender imbalance in teaching materials. Hellinger (1980) and Gaff (1982) in their study found that the textbooks they investigated contained some sexist language patterns and sexist attitudes. At the beginning of 1990s, a voluntary British group published a document On Balance: guidelines for materials writers in EFL-'a set of guidelines on how to write materials that treated both sexes with equal dignity and gave them equal coverage' (Florent et.al., 1994: 112). Some positive effects of this document are acknowledged by Jones etal. (1997) and Toussidou (2001). They found more balanced gender representation in English textbooks.

In recent times, the $2000 \mathrm{~s}$, the studies are not focused solely on texts but also on the use of texts in language classrooms. Sunderland et al. (2001) have conducted a study focusing on a set of lessons involving gendered texts in a textbook. The results show that the teacher's talk cannot be predicted from the textbook text itself because 'traditional' texts might be being endorsed and 'progressive' texts undermined (ibid, 2001: 252). A similar study by Balfour (2003) focusing on female and male pupils' responses to texts dealing with gender relations indicate that teacher's talk around gendered texts contributes to raising students' awareness of gender representation. (See Peterson \& Lach, 1990; Kortenhaus \& Demarest, 1993; Wharton, 2005 for more similar studies).

Observing the plethora of attempts to inculcate equal gender representations in school textbooks endorsed by the western countries, I am now concerned with what has happened in the (South East) Asian contexts. Literature and/or studies addressing such issues are less frequent than in the Western contexts. Some studies scrutinizing gender matters in language textbooks in this region are those in the context of Singapore, Hong Kong, and Indonesia. All of them indicate similar results where textbooks perpetuate gender imbalances.

Gupta and Lee's (1990) research on gender representation in English language textbooks in Singapore yielded that there were significant gender imbalances in the female-male ratio and in the amount of speech given to characters and in rolerepresentation. Lie (2001) investigated 42 textbooks used in Indonesia and found that there are stark gender imbalances in terms of frequency of male and female characters in the reading passages and pictures supporting the reading texts. In 2004, a survey conducted by the City University of Hong Kong indicated similar results in which the males significantly outnumber the females (McGrath, 2004).

Most of the studies mentioned above focus more on the frequency or ratio between male and female gender and less focus is given to the gender roles and actions in interactional and/or transactional processes. In the light of this gap, I conducted a textual analysis on four English language textbooks used in Indonesian primary schools. The focus of the study is on the pictorial texts accompanying the linguistic ones. Those texts are not regarded as 'merely' accompanying illustration to verbal texts because meaning construction is multimodal. The 'Visual Grammar', developed by Kress and van Leeuwen (2006) as an adaptation from Halliday's Systemic Functional Linguistics, is used as the framework to analyze the texts. Specifically, the focus of this study is formulated in the following research questions: (1) How are the female and male characters depicted in the 
illustrations?, (2) What are their roles?, and (3) What kinds of processes are collocated with the female and male characters?

\section{Gender Issues in Indonesia}

As regards gender equality, Indonesian government has formally addressed this in the 1945 Indonesian Constitution, 'which does not differentiate or discriminate between men and women in the workforce, health, politics or law (Masruchah \& Keenan, 2005: 170). However, as reported by Masruchah and Keenan (2005), women's rights in Indonesia are often ignored.

Even though Indonesia consists of many ethnics and cultures, the people tend to share similar views regarding men and women. Men are valued more than women (Masruchah \& Keenan, 2005) and educated more thoroughly than girls with an assumption that higher education for girls is only a waste of money because they will finally end up with marriage and raise children. This is reflected in a famous rhyme throughout the country describing domains of a woman's activity which is called the three -ur:: sumur, dapur, kasurr ('a well' for washing up, 'a kitchen' for cooking, and 'a bed' for providing pleasure for her husband).

Therefore, after graduating from primary education (or if lucky enough to experience high school) many girls are married off and some of them are married earlier than the average age of marriage (18 years old) to 'avoid the 'danger' of pre-marital sex, or of ending up as 'spinster' or 'old virgins' (ibid: 170). Such conditions might de-motivate female students to pursue higher education.

Despite the prevalence of traditional views of women's roles, nowadays due to economical urges especially in big cities women are expected to work to support her family's economy. According to Gallaway and Benasek (2002) who quote the United Nations' report that in 1995, 65 percent of economically active Indonesian women participate in the informal sector of economy. By the term informal sector, they (ibid: 314) refer to as ' $a$ heterogeneous group of economic arrangements... which includes both selfemployment (home production and petty trading) and wage employment (casual labor, contract labor, and piecework)'.

Several reasons are responsible for women's excessive participation in the informal sector. Gallaway and Benasek (2002) explain that from the positive view, working in the informal sector is considered better for women because many activities in this sector can be done at home so as to allow women to combine household work with paid work. On the opposite view, women are actually forced to participate in the informal sector because their household responsibilities are not accommodated by the formal sector. However, these two different views agree that family responsibilities are determining factors that influence women's decision to participate in the labor force.

Whilst many Indonesian women participate in the informal sector which according to Gallaway and Benasek (2002) is inferior to the formal sector in terms of earnings and security, the number of Indonesian women who work as professionals is also growing. Ten years from the data given by the United Nations, in 2005 the Indonesian department of labor and transmigration reported that the number of women (1,779,688 people) who have got professional jobs outnumber the men (1,707,960 people). This shows that many Indonesian women have empowered themselves to get jobs that require special 
education and training despite their family responsibilities.

The fact that nowadays more Indonesian women have greater possibilities to work in the formal sectors should be made known throughout the country. One of the ways is through EFL textbooks that present various roles of women in the formal sector so as to encourage more female students to pursue higher education for their better future and more involvement in the formal sector.

\section{Gender Stereotypes in children's books and EFL textbooks}

Based on some studies conducted during the 1970-80s on children's literature and textbooks (see Zimet, 1976; Hellinger, 1980; Gaff, 1982; Peterson \& Lach, 1990; and Kortenhous \& Demarest, 1993), stereotype patterns about females and males were consistently portrayed. The number of female characters was always significantly less than the males. The females were likely to be depicted as being nurturant, dependent, passive, submissive, helpless, incompetent, and unambitious. They were also limited in what they did and were assigned few goals or occupations which were seen prestigious in the society; there was even almost no portrayal of a mother working outside home. On the other hand, males were represented as being competent and achievement oriented, more instrumental and independent, more engaged in outdoor activities, capable of solving problems, more powerful and assigned a greater range of occupational roles than women.

The studies discussed above and other similar studies arguably resulted in raising the awareness of equal gender representation. This trend was captured by Kortenhaus and Demarest (1993) who investigated a variety of children's books published from the 1940s-1980s. More equal representation of females and males was also identified in a study of textbook dialogues done by Jones et. al. (1997) and Toussidou (2001). They gave a credit of this progression partly to the publication of On Balance: Guidelines for the Representation of Women and Men in English Language Teaching Materials by Women in EFL in 1991. Yet, this improvement does not mean that stereotyping patterns that demean the women has been eliminated.

In the 1990s some studies show that despite more equal number of the female and male characters, kinds of qualities assigned to the female and male characters are still imbalanced. Jones et. al. (1997) have quoted Poulou's (1997) research results that in the textbook dialogues used in Greece, women were likely to ask for information and men to provide it, and women tended to use the expressive language more than men. Furthermore, as summarized by Sunderland et. al. (2001) from various studies on dialogue textbooks, females tended to speak less, to initiate a conversation less often, and performed a narrower range of discourse roles.

In the same decade when some progressive texts were produced more in the western countries, in different parts of the world such as Singapore, stereotype patterns of females and males similar to those in the 1970s were identified in the primary textbooks investigated by Gupta and Lee (1990). In those textbooks, the roles of female were very limited and mainly centered on nurturing professions such as teaching, food preparation and serving and nursing; there was almost no job requiring specialist knowledge for women. Ten years later or so, a study in Hong Kong (Mc Grath, 2004) also indicated almost the same results: the males outnumbered the females; and the 
males were cast as courageous and the females as weak.

\section{Textual Analysis}

This study, which deals with EFL textbooks, focuses its analysis on what is on the page i.e. the analysis of text. The term 'text' here carries a broader meaning that includes visual images. My motivations to do the textual analysis are to uncover and to raise consciousness of what is going on in society i.e. gender representation as reflected in the textbooks which I believe is profoundly influenced by the society-in this case the contemporary Indonesian context (see section 2. review on gender issues in Indonesia).

Textual analysis as Fairclough (2003a) argues has possible capability to reveal social events and casual effects embedded in texts. He mentions that part of the analysis of texts is trying to identify what is assumed in a text and to understand its consequences because "what is 'said' in the text always rests upon 'unsaid' assumptions" (ibid: 11). In line with it, Stein (2004: 106) contends that text is a representation of its maker's interest that emerges from " $a$ complex combination of the demands of the particular social occasion... and the social, cultural, and historical characteristic of the individual maker...". This supports the idea that text is never free from its author's view about the world s/he lives in because their world greatly contributes to shaping their view. Through the analysis of text, therefore, understanding and raising consciousness to social practices where the text is produced such as ideology, social justice and power will be made attainable.

However, Fairclough (2003a) admits that textual analysis by itself is not enough but when it is combined with other methods of analysis, such as critical discourse analysis, it can serve as a useful resource for social research. Detailed textual analysis, for instance, is claimed by Fairclough (1999) is potential to strengthen discourse analysis. Thus textual analysis is conducted as a first step of discourse analysis whose investigation goes beyond the text. In this study, 'text' and 'discourse' will be differentiated despite confusion over these two terms (Widdowson, 2003a; Wodak, 1997).

Text is a product and discourse is a process of social interaction (Fairclough, 1999). The process that discourse embodies includes the process of text production and the process of text interpretation which are socially determined (ibid, 1999). In these processes, people who produce and interpret text are influenced by social conditions which make them selective in using the language and make them "see things in a particular way and follow a particular kind of discourse" (Butler and Keith, 1999: 85). It is thus inevitable that text and discourse are inseparable.

As far as text and discourse are concerned, school textbooks analyzed in this study can be described as texts containing a gendered discourse. Here, school textbooks reflect how social practices treat gender matters. The choices of language and pictures in the textbooks are socially determined by how people construe social roles between women and men. On the other hand, the school textbooks can also be described as texts which are part of a wider discourse i.e. the discourse of EFL materials in Indonesia. Within this discourse, the school textbooks are produced and interpreted in a framework shaped by the EFL discourse community in Indonesia.

However, the two positions of EFL textbooks mentioned above are not 
separately exclusive. As part of discourse of EFL materials, school textbooks are intentionally designed to be 'read' by school students - for this study, primary students. When reading these texts, they are automatically exposed to gendered discourse contained in the textbooks which in effect may contribute to shaping their ideas about gender (Zimet, 1976; Littlejohn \& Windeatt, 1989: Peterson \& Lach, 1990; Kortenhaus \& Demares, 1993; Wharton, 2005). It is hence important to scrutinize texts used by primary students because these texts may havean influence on the students' psyches as they develop their own social identities (Wharton, 2005).

\section{Text: Linguistics and Pictorial}

As textual analysis it is imperative for this study to clarify some terminologies dealing with 'text'. According to Halliday \& Mathiessen (2004: 3) a text refers to "any instance of language, in medium, that makes sense to someone who knows the language". Similar definition which closely relates a text to language is also offered by Bloor and Bloor (2004), a text is any stretch of language spoken or written for human communication in actual circumstances. From these two definitions, the term 'text' is limited to the use of language as a means of communication by excluding other means of communication i.e. the use of nonlinguistic features.

Goatly(2000: 3) puts his definition of text in a more open way; text is 'the physical form which the writing (speaking) takes on the page (in the air) and the meanings which this physical form encodes". He does not specifically mention the language as the medium; he terms it as 'physical form' instead. I think, this term brings broader implication that text is not only in a form of language but also other forms such as pictures and sounds.

The broader sense of text is also acknowledged by Fairclough (2003a) that text is any actual instance of language in use which includes written and printed texts, transcripts of spoken conversation and interviews as well as television programmes and webpages. Yet, he realized that the use of language to characterize a text is limiting because texts such as television programmes involve visual images and sound effects. Text, hence, covers written and printed texts (linguistic features) such as newspaper and textbooks, as well as illustrations and sounds (non-linguistic features).

In this study, I will employ the term 'text' in a broader sense because the object of the study is EFL textbooks which are also 'text' as "a whole written documents" (Sunderland, 2001: 253) consisting of linguistic texts and non-linguistic texts. Specifically I will look closely at a shorter stretch of written (linguistic) texts such as reading text, exercises, activities, and dialogues, and pictorial texts such as illustrations accompanying the linguistic texts. Involving two complementary texts such as linguistic and pictorial texts can contribute to more comprehensive meanings. As claimed by Yuen (2004) to limit the linguistic texts and disregard the pictorial texts in the textual analysis can lead to eradicating the development of meaning emerging from the mixture of different types of texts.

\section{Juxtaposition of Linguistic Texts and Visual Images}

As elaborated previously, text as the term is used in this study does not only refer to verbal text but also visual text because meaning making is multimodal involving visual, gesture, speech, writing, and sound through which representation occurs 
(Stein, 2004). This is in line with Fairclough's et al. (2004) claim that social construction of meaning is never solely represented linguistically but also vocally and visually. However, until recently visual text has often been regarded as 'merely' accompanying illustration to verbal text (Fei, 2004). But now, more studies with the nature of interactions between the verbal and the visual texts in various genres and in various disciplines are required especially when involving learners from non-English speaking backgrounds where the visual images need to be related to the verbal resources in English (Guo, 2004). To this respect, verbal and visual texts are juxtaposed in this study.

Fei (2004: 220) has proposed an Integrative Multi-Semiotic Model (IMM) expounded by Lim (2002) as 'a metamodel for the analysis of a page or frame which involves the use of both languages and pictures as semiotic resources.' See Figure 1.

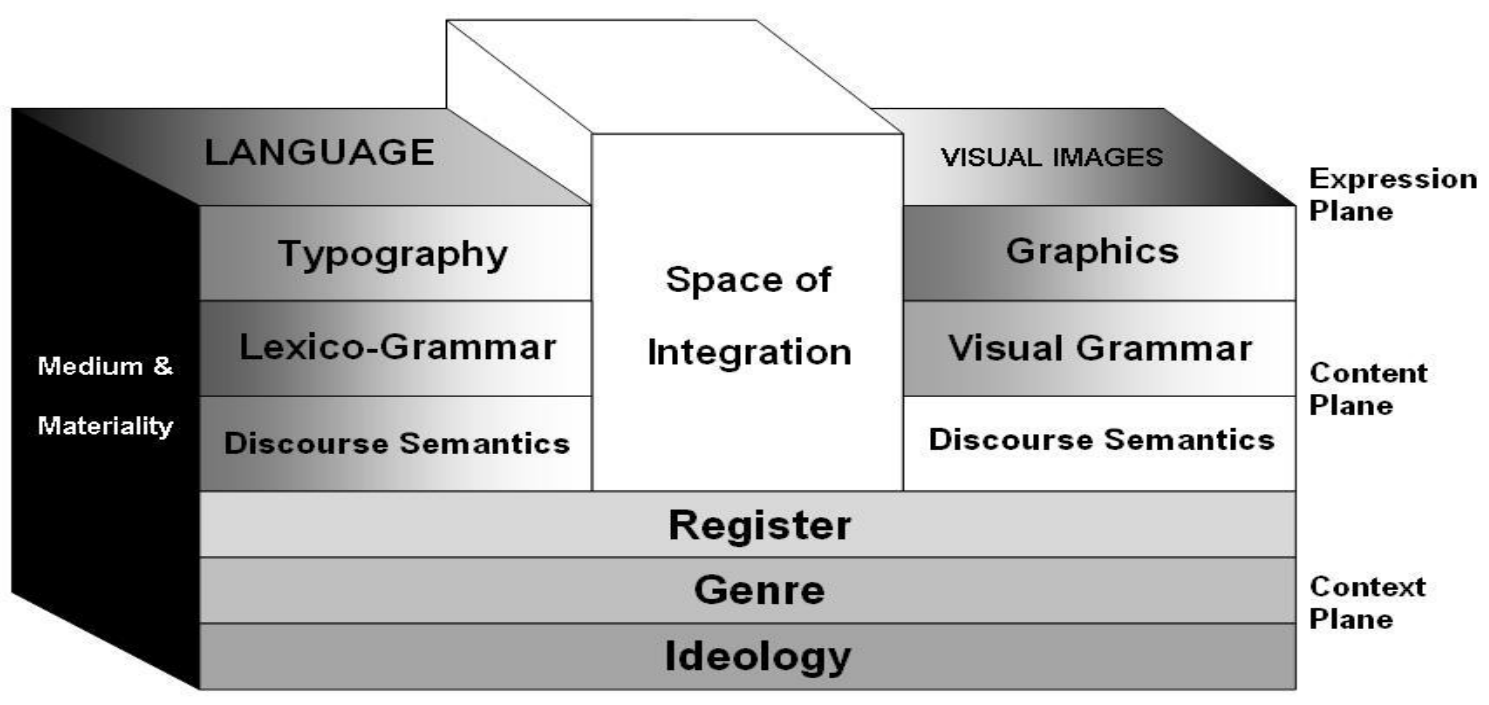

Figure 1: Lim's Integrative Multi-Semiotic Model (Fei, 2004: 220)

Fei (2004) explains that the blocks in the IMM metaphorically represent the strata, planes and dimensions of meaning within and across language and visual images. As we can see the Expression plane is divided into typography and lexico-grammar for the language, and graphics and visual grammar for the visual images. The Content plane comprises discourse semantic; the Context planes consist of register, genre and ideology.

The language and visual images as further elaborated by Fei (2004) interact, negotiate and construct a meaning in a space called "Space of Integration" (SoI), which is depicted as an elevated platform between the linguistic and pictorial modalities in the IMM.

Fei (2004) argues that Halliday's three metafunctions (i.e. the Ideational, Interpersonal, and Textual metafunctions) organize the systems of meaning in the Expression and Content plane for language and visual images. However, the present study only focuses on the Ideational metafunction specifically the experiential meanings which operate in visual images. 


\section{Visual Grammar}

Visual grammar is developed based on Halliday's Sytemic Functional Linguistics which is originally conceived for linguistic text (Fei, 2004). Like linguistic text, visual text fulfills three major functions: ideational which is the main concern of this study, interpersonal and textual functions (Kress and van Leeuwen, 2006). Nevertheless, this does not imply that visual texts work in the same way as the linguistic ones; there are some ways of representing the world which can only be described by language, or solely by visual image, or by both (Kress and van Leeuwen, 2006). For example, as Kress (2004) explains, if I said, "Asrul and Dewi are getting married", it shows that I had a closer relationship to Asrul as I mentioned his name first. He was more important. To the listeners who did not know the couple, it would be vague as they were not informed regarding how tall Asrul is, what age Dewi, and so on. By contrast, if I showed a picture of the couple, much of this would be clear to the readers.

According to Kress and van Leeuwen (2006), visual texts in representing aspects of the world as it is experienced by humans offer choices of different ways in which objects and their relations to other objects and to processes can be represented. The choices could be Narrative or Conceptual Representations.

In the narrative, for instance, a process of interaction between two objects may be visually realized by a vector.

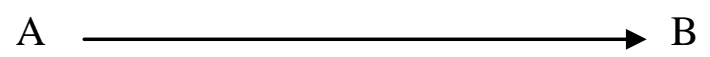

Fig. 2 Vector (from Kress and van Leeuwen, 2006)

The realizations of the processes formed by a vector emanating from one participant (e.g. Actor) to another (e.g.
Goal) are varied. The variations are summarized in Table 1.

Table 1: The narrative structures

\begin{tabular}{|l|l|}
\hline \multicolumn{2}{|c|}{ Processes } \\
\hline Action & $\begin{array}{l}\text { Transactional: } \\
\text { a. Unidirectional: a vector connects two participants (i.e. } \\
\text { Actor - Goal). } \\
\text { bidirectional: a vector connects two Interactors (i.e. the } \\
\text { participants where the vector could be said to emanate from } \\
\text { and be directed, at both participants). }\end{array}$ \\
\cline { 2 - 4 } & $\begin{array}{l}\text { Non transactional: a vector which emanates from a participant (i.e. } \\
\text { Actor) is not 'done to' or 'aimed at' anyone or anything (no Goal); } \\
\text { it represents events. }\end{array}$ \\
\hline Reactional & $\begin{array}{l}\text { Transactional Reaction: an eyeline vector connects two participants } \\
\text { (i.e. Reacter-Phenomenon) }\end{array}$ \\
\hline Projective & $\begin{array}{l}\text { Non-transactional Reaction: an eyeline vector emanates from a } \\
\text { participant (i.e. Reacter) but does not point at another participant } \\
\text { (no Phenomenon). }\end{array}$ \\
\hline $\begin{array}{l}\text { Mental: a vector formed by a 'thought bubble' connects two } \\
\text { participants (i.e. Senser-Phenomenon) }\end{array}$ \\
\hline
\end{tabular}




\begin{tabular}{|c|c|}
\hline & $\begin{array}{l}\text { Verbal: a vector formed by a 'speech bubble' connects two } \\
\text { participants (i.e. Sayer-Utterance) }\end{array}$ \\
\hline Conversion & $\begin{array}{l}\text { This process represents a change of state of its participants i.e. a } \\
\text { participant is the Goal of one action and the Actor of another }\end{array}$ \\
\hline \multicolumn{2}{|c|}{$\begin{array}{l}\text { Circumstances } \\
\text { (secondary participants which relate to the main participants but not by means of } \\
\text { vectors) }\end{array}$} \\
\hline Setting & $\begin{array}{l}\text { a relation of other participants to a specific participant by a contrast } \\
\text { between foreground and background }\end{array}$ \\
\hline Means & the tools used in action processes \\
\hline Accompaniment & a participant which has no vectorial relation with other participant \\
\hline
\end{tabular}

In the conceptual representation objects

related in terms of classification may be

visually realized by a tree structure.

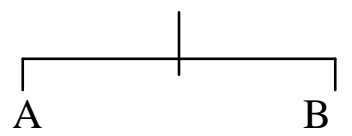

Figure 3: Tree Structure (from Kress and van Leeuwen, 2006)

But, this is not the only way to realize a process in the conceptual structure. See more processes in Table 2.

\section{METHOD}

In this study, I examine four English textbooks for primary schools that are widely used and published in Indonesia. They are Go with English (2005), Learning by Doing (2004), Grow with English (2002), and Fokus (the year of publication is not available). Henceforth they are called as GE, LD, GrE, and F respectively. The level of those textbooks are for beginners intended for year- four students to which English is officially introduced.

The first step of the study is to classify 'gendered' texts, i.e. texts about people or people-like (Sunderland et al, 2001: 260). These texts may take forms of 'linguistic' and 'pictorial' texts (Fei, 2004: 228). Linguistic texts cover reading passages, exercises, and dialogues. Pictorial texts cover any visual images

Table 2: The Conceptual Structure about people/people-like that accompany the linguistic texts. In these textbooks, visual images almost never appear alone but always as support to reading passages, exercises, and dialogues.

The next step is to select purposively pictorial texts that involved female and male characters. Due to time and space limitation, only one pictorial text was taken from each textbook. They were then analyzed in terms of their Representation structure. The following is a brief description of each picture.

Picture 1: accompanying two sets of dialogue using speech bubbles in Learning by Doing $(L D)$.

Picture 2: accompanying a reading passage in Fokus $(F)$

Picture 3: accompanying a set of dialogue without speech bubbles in Go with English (GE)

Picture 4: accompanying a set of dialogues without speech bubbles in Grow with English (GrE). 


\begin{tabular}{|l|l|}
\hline Processes & \\
\hline Classificatory & $\begin{array}{l}\text { Overt: the participants are represented in a tree structure that indicates } \\
\text { different levels of participants (i.e. Superordinates-Subordinates) }\end{array}$ \\
\cline { 2 - 3 } & $\begin{array}{l}\text { Covert: the arrangement of participants (i.e. Subordinates) belonging to } \\
\text { the same class }\end{array}$ \\
\hline Analytical & $\begin{array}{l}\text { It relates two kinds of participants: Carrier (the whole) and Possessive } \\
\text { Attributes (the parts). }\end{array}$ \\
\hline Symbolical & $\begin{array}{l}\text { Attributive: relating a participant (i.e. Carrier) to another participant } \\
\text { which represent the Carrier's meaning or identity (i.e. Symbolic } \\
\text { Attribute) }\end{array}$ \\
\cline { 2 - 2 } & $\begin{array}{l}\text { Suggestive: it represents one participant (i.e Carrier) which is analogous } \\
\text { to Existential in Halliday's SFL. }\end{array}$ \\
\hline
\end{tabular}

FINDINGS AND DISCUSSION

This section presents the results of the textual analysis by focusing more on the roles and types of actions that the female and male characters perform in interactional/transactional processes.

\section{Picture 1}

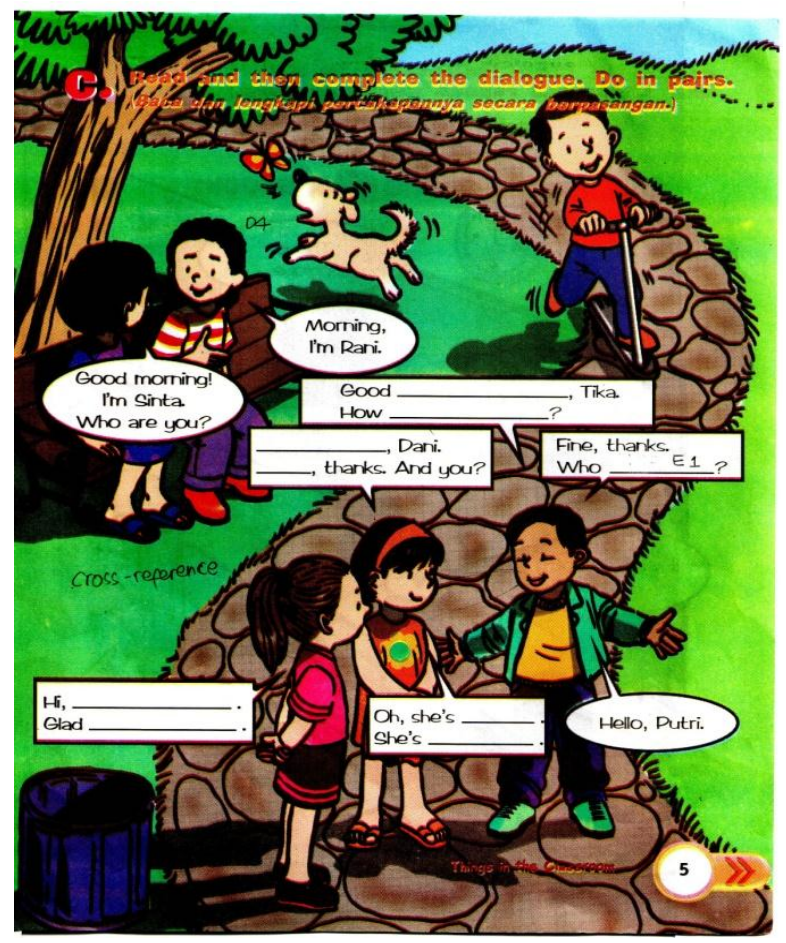

In $L D$ (p. 5), the illustration accompanying two sets of dialogues is presented in one full page and is shown as one united piece of picture which is mainly about children in a park. From this page the students are asked to read an example of a complete dialogue and then complete another dialogue which is incomplete. There are three main groups of participants depicted in this picture i.e. Group (1) a boy riding a scooter in a foot path, Group (2) two girls sitting on a 
bench and talking (evinced by a complete dialogue in speech bubbles emanating from these two girls), and Group (3) two girls and a boy standing on a foot path and talking (evinced by incomplete dialogue in speech bubbles emanating from them).

Due to its semiotic salience, Group 3 will be firstly discussed. Based on the vector made by the eyes' lines emanating from the participants in Group 3, it is clear that the boy is the center of the gaze as evinced by the fact that there are more participants (two girls) looking at him. Despite being the center of the gaze, he is not necessarily the Goal because as supported by the linguistic evidence, the process happening in this image is the Bidirectional Action in which the participants involved can play as both the Actor and the Goal.

Juxtaposing the linguistic items and the images, we can see that the boy initiates the dialogue. It is yielded by a vector which emanates from the boy to his speech bubbles containing greeting "Good ........(morning), Tika." and a question "How .....(are you)?" Usually the one who initiates the discourse tends to be more powerful because $\mathrm{s} / \mathrm{he}$ is the one who can control or lead the discourse. The control of this boy over the conversation with the girls is supported by his gesture which depicts him spreading his arms wide open as if he is about to embrace or reach his counterparts. This may possibly be interpreted as inviting the girls to enter into his 'realm' or to take them into a social interaction under his control.

Gestures made by the girls also strengthen this interpretation. The way they keep their hands closed/crossed suggests that either they are being cautious or uncertain or afraid of 'embracing' the world outside including the boy's world or they are trying to be 'a girl' expected by the society who is not aggressive towards men and who knows the boundary between a girl's and a boy's world. I would argue that the image of this group together with the linguistic evidence is a depiction influenced by patriarchal values in which men is more powerful and significant than women.

This argument is also supported by the depiction of the other two groups where a boy riding a scooter is depicted to be able to enjoy his activity despite without the presence of others whilst the girls seem to be able to enjoy themselves 'only' when there is a company to talk to who is also from the same gender.

Seen from the process construed in the image of Group 2, both girls are the Actors and the Goals of Bidirectional Transactional Action. The interaction between them is depicted to be more intimate, relaxed, and free than the other two girls in Group 3. It is evinced by the proximity between the girls and the gesture of one of the girls' hand.

The boy in Group 1 is the Actor of Unidirectional Transactional Action in which the children in Group 3 are the Goals. It can be explained by looking at the vector emanating from his gaze and the direction of his scooter toward Group 3 who are standing on the same foot path. It suggests that even though he is alone, he can put himself as an independent active participant. This boy is the one who takes initiation to do something and he is able to do it by himself. 


\section{Picture 2}

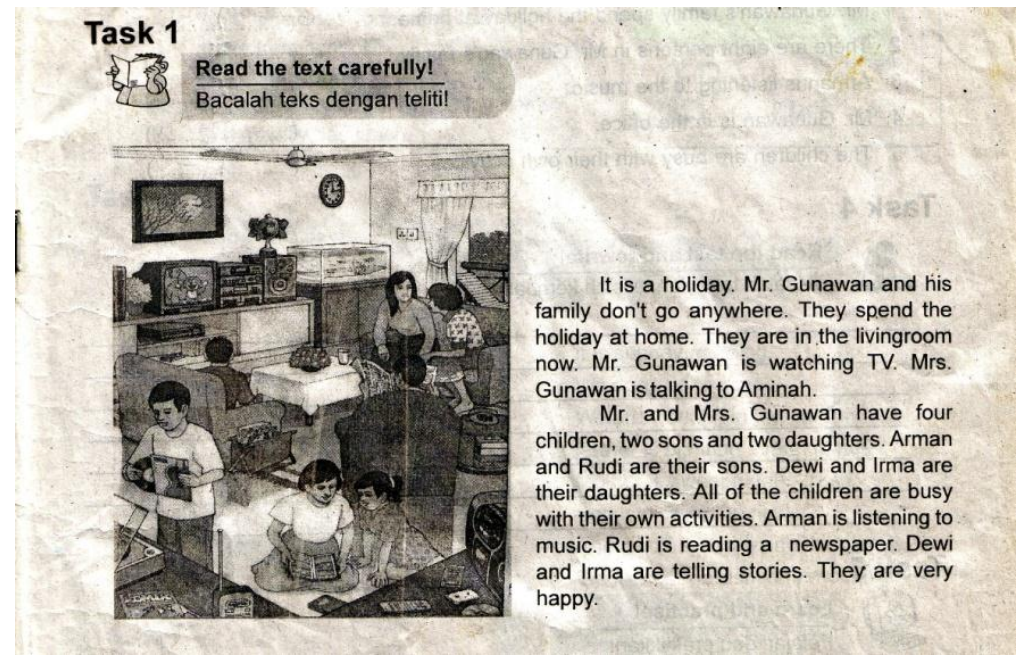

A picture accompanying a reading passage in $F$ (p. 3) is about $M r$. Gunawan's family spending their holiday at home. Both the text and the picture describe the activities of eight main participants i.e. four women and four men. As confirmed by the text, all participants are very happy doing their own activities.

The analysis will start from two girls sitting on the floor and doing a story telling (mentioned in the passage). Based on the vector formed by the heads of the girls which are directing to each other and their gaze towards a book on one of the girls' lap, these girls can be assigned as the Actors and the Goals of Bidirectional Transactional Action and also the Actors of a Unidirectional Transactional Action in which the book is the Goal. The girls seem to be happy to tell each other stories from a book.

Similarly, two other women sitting on a sofa are depicted to talk to each other. Their eyes' lines form and the direction of their bodies towards each other form a vector which suggests that they are the Actors and the Goals of the same process i.e. a Bidirectional Transactional Action. As the text affirms, these two women are also happy talking to each other.

Different depiction is shown for male participants, where none of them is depicted to do the activities together. $M r$. Gunawan (the Actor), for instance, is shown enjoying watching a TV (the Goal) by himself. Two of his sons also enjoy their own activities where Arman (the Actor) is reading a newspaper (the Goal) and Rudi (the Actor) is playing a CD (the Goal).

From picture 3, we can see that females and males are represented differently. Women are shown to be more social than men as they were shown doing things together with other people. At the same time, men are also described as being independent where they are shown as being able to do things by themselves. 


\section{Picture 3}

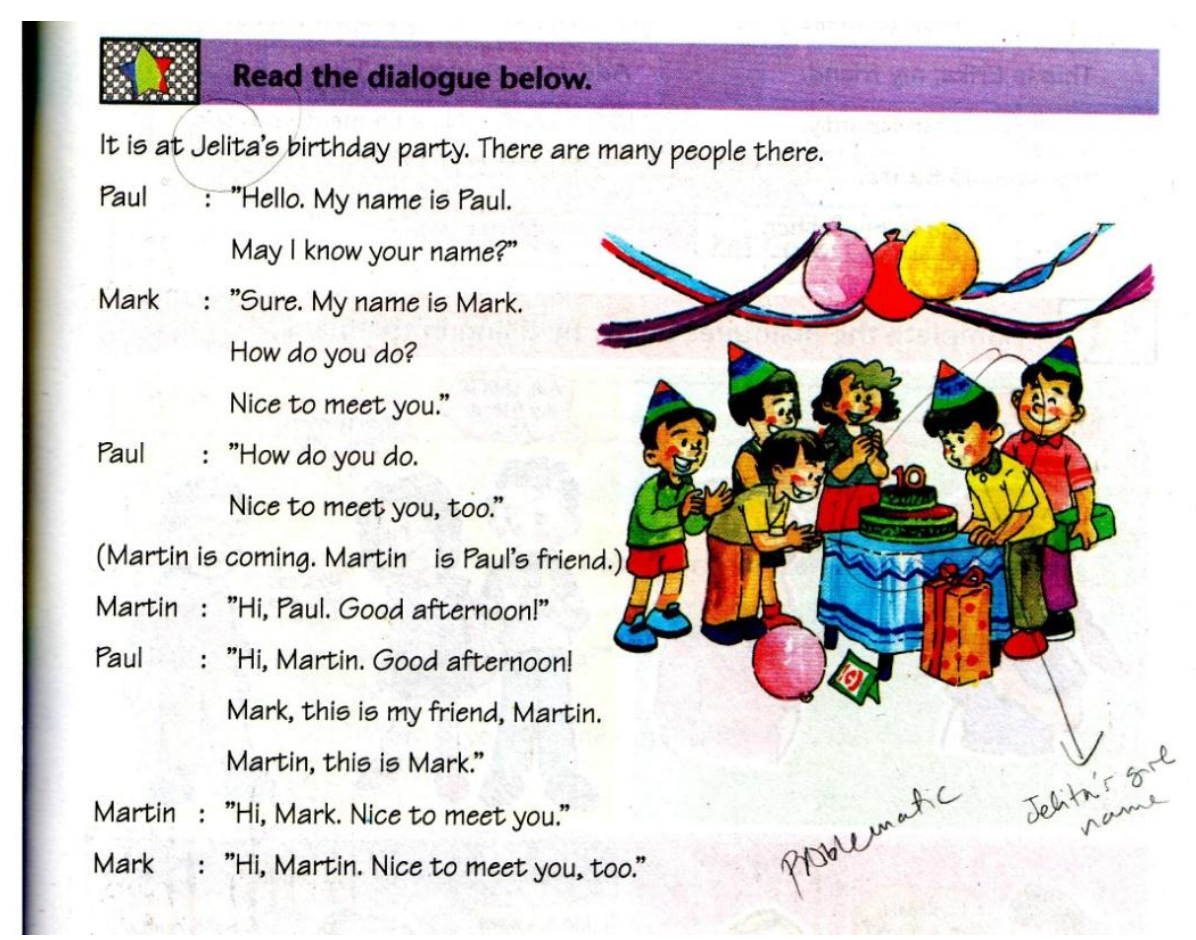

In $G E$ (p. 29), a dialogue without speech bubbles is accompanied by an illustration depicting a child's birthday party. The introduction of the dialogue mentions that 'it is at Jelita's birthday party', Jelita in the Indonesian context is a girl's name which means beautiful. Hence, we can predict that the dialogue is about Jelita's birthday but surprisingly both the picture and the dialogue do not depict and mention Jelita at all. In the picture a child who blows the candles is a boy and participants involved in the dialogues are also boys. It seems that there is almost no connection at all between the picture and dialogue.The disconnection might be as simple as editorial errors where the illustrator took the gender issue for granted. Suppose there was miscommunication between the writer and the illustrator, the illustrator took the common tendency to present the boy in the picture.

There are two kinds of processes represented by this picture. First, 'a boy blowing the birthday candles' is the Actor of the Transactional Action in which the candles are the Goal, this can be seen from the whole angle of his body which forms a vector between him and the candles. This shows that the boy are the active agent who is able to do something. Second, this process then becomes the Phenomenon of a reactional structure in which other children (two girls and three boys) surrounding him are the Reacter-vectors, formed by the direction of their gaze and body's angle, emanate from them to the boy. In this process, the boy is depicted as a male who invites admiration from others for the action that he performs. 


\section{Picture 4}

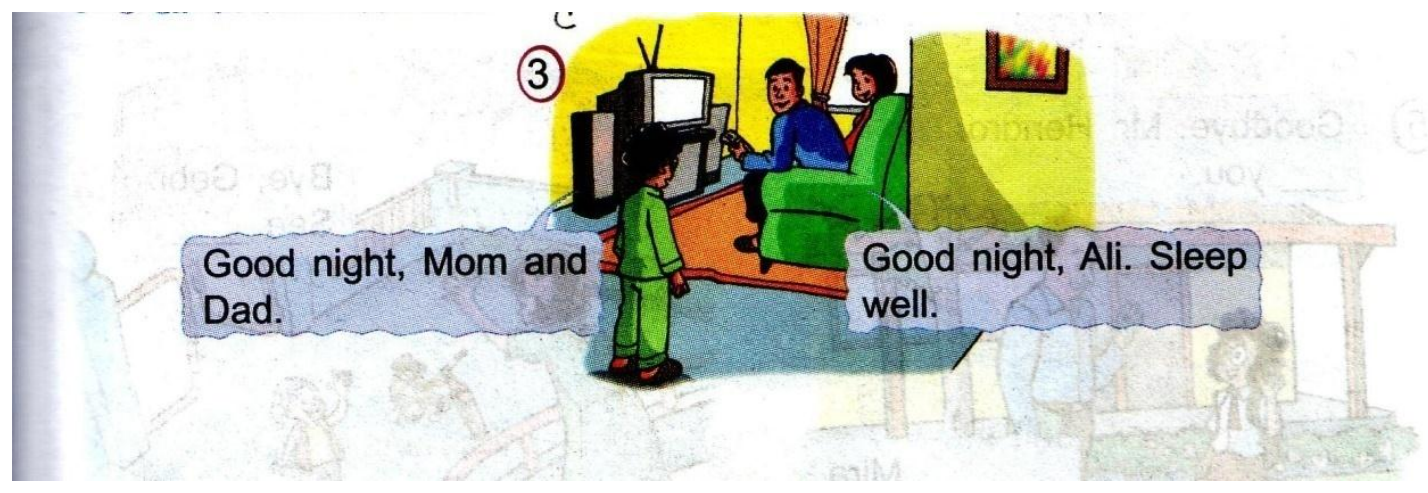

A picture in $G r E$ (p. 9) is shown together with speech bubbles projected from some participants involved in a dialogue. There are three main participants depicted in the picture: a mother, a father, and a son but only the father and the son who have the conversation as evinced by the speech bubbles emanating from them. The son and the father are both the Actors and the Goals - a bidirectional vector is formed by the direction of the father's head towards his son and the angle of the son's body towards his parents. Then this process becomes the Phenomenon of a Reactional process in which the mother is the Reacter-an eye line is formed by the direction of her glance and her head to her husband and son. She reacts to her husband and son's action with smile. This kind of process according to Goffman in Kress and van Leeuwen (2006: 67) suggests that the man is the 'doer' whilst the woman as a 'faithful admirer of his actions'.

Observing another vector emanating from the parents, we can also say that they are the Actors of a Transactional Action in which a television is the Goal-a vector, formed by the angle of the father's body and hand and the direction of the mother's body, leads from them to the television. It shows that father and mother can do something together at night in a living room watching television.

All in all, as shown by the sample of four pictures from the textbooks, there is no significant asymmetry found in number between the female characters (11) and the male characters (12). Both females and males are depicted almost equally as the Actors (female: 10, male: 8) and the Reacter (female: 3, male: 3) but stark differences occur in terms of Goals (female: 10, male: 4) and Reacters (female: 0, male: 3 ).

Even though the females are numerically dominant being the Actors, they are also dominant as the Goals as they are mostly involved in the Bidirectional Actions. In these processes the females are 'doing to and being done by' someone else. Different from the females, the males in the Unidirectional Actions are more dominant; they are cast as the Actor who is 'doing' to something. In the Transactional Reactions, both females and males are depicted as the Reacters but only men as the Phenomenon.

I would conclude that the space of integration (SoI) between linguistic texts and visual images in these four pictures tend toperpetuate the stereotypical 
imbalance of gender representation in which the boys are depicted to be more significant, independent and active whilst the girls to be dependent, passive, and restricted.

\section{CONCLUSION}

As a textual analysis, this study has progressed further than investigating the linguistic texts solely; it looked at the visual images. The findings have indicated that there is a gender imbalance represented in English language textbooks for primary students in Indonesia. Surprisingly, pictures in these textbooks perpetuate a biased gender representation which was mostly found during the 1970s and 1980s in the Western countries when 'political correctness' in gender matters was not well established.

Illustrations accompanying linguistic texts fortified the representation of gender asymmetry. Both sexes were almost equally cast as the Actors but of different processes; the females were more of the Bidirectional in which the actions were reciprocally aimed at both participants whilst the males were more of the Unidirectional in which the actions only emanated from them. It suggests an idea that in the processes of 'doing' the females tended to need a partner whilst the males tended to be more independent. Both sexes were also construed as the Reacters but only males as the Phenomenon. In this case, the females tended to be the admirers of an action carried out by the males. As pictures are potentially construing meanings, conscious efforts to incorporate gender symmetry in visualizations would be preferable.

\section{TEXTS ANALYSED}

Kurniawan, R. 2005. Go with English. Bogor: Yudhistira.
Mukarto. 2002. Grow with English. Jakarta: Erlangga.

Sukasno, A. ND. Fokus. Solo: CV. Sindhunata.

Suyanto, K. E. K. 2004. Learning by doing. Bandung: Grafindo.

\section{REFERENCES}

Balfour, R. (2003). "Between the lines: Gender in the reception of texts by schoolchildren in rural KwaZulu-Natal, South Africa [1]" in Gender and education, 9(3): 469-490

Bloor, T. \& M. Bloor. (2004). The functional analysis of English. London: Arnold.

Butler, M. \& G. Keith. (1999). Language, power, and identity. London: Hodder and Stoughton.

Fairclough, N. (1999). "Linguistic and intertextual analysis within discourse analysis" in A. Jaworski and N. Coupland (eds.)

Fairclough, N. (2003a). Analyzing discourse: Textual analysis for social research. London: Routledge.

Fairclough, N., P. Graham, J. Lemke, and R. Wodak. 2004. "Introduction" in Critical Discourse Studies 1(1), pp. 1-7.

Fei, V.L. (2004). "Developing an integrative multi-semiotic model" in K.L.

O'Hallloran (ed.). Multimodal discourse analysis: Systemic functional perspective: London: Continuum

Florent, J., K. Fuller, J. Pugsley, C. Walter and A. Young. (1994). "On balance: guidelines for the representation of women and men in English language teaching materials" in J. Sunderland (ed.)

Gaff, R. (1982). "Sex-stereotyping in modern language teaching - an aspect of the hidden curriculum" in British Journal of Language Teaching xx (2), pp. 71-78.

Gallaway, J.H. and A. Benasek. (2002). "Gender and informal sector employment in indonesia" in Journal of Economy Issues, xxxvi (2), pp. 313-321. Retrieved from http://diglib.lib.utk.edu/utj/jei/36/jei-362-7.pdf. 
Goatly, A. (2000). Critical reading and writing. London: Routledge.

Gupta, F.A. \& S.Y.A. Lee. 1990. “Gender representation in English language textbooks used in Singapore primary schools" in Language and Education, 4(1), pp. 29-50.

Guo, L. (2004). "Multimodality in a biology textbook" in O'Hallloran, K. L. (ed.).

Halliday, M.A.K. \& C.M.I.M. Mathiessen. (2004). An introduction to functional grammar. London: Arnold.

Hellinger, M. (1980). "For men must work and women must weep: Sexism in English language textbooks used in German schools" in Women's Studies International Quarterly, 3, pp. 267-275.

Jones, M., C. Kitetu \& J. Sunderland. (1997). "Discourse roles, gender and language textbook dialogues: who learns what from John and Sally?" in Gender and Education,9(3), pp. 469-490.

Kortenhaus, C. M. \& J. Demarest. (1993). "Gender role stereotyping in children's literature: An update" in Sex Roles 28 3(4), pp. 219-232.

Kress, G. (2004). "Reading images: Multimodality, representation and new" in

Mediahttp://www.knowledgepresentation .org/BuildingTheFuture/Kress2/Kress2.ht $\mathrm{ml}$.

Kress, G. \& T. van Leeuwen. (2006). ( $2^{\text {nd }}$ ed.). Reading images: The grammar of visual design. London: Routledge.

Lie, A. (2001). "Multicultural issues in the 1994 English curriculum in Indonesian Senior High Schools" in Renandya, W.A. \& Sunga, N. (eds.). (2001).

Language and instruction in multicultural societies. Anthology Series 42. Singapore: SEAMEO Regional Language Centre.

Littlejohn, A. \& S. Windeatt. (1989). "Beyond language learning: Perspective on materials design" in Johnson R.K. (ed.).

Masruchah \& B. Keenan. (2005). "Working from within: Using the legitimacy of religion to create change in Indonesia" in G. Misra \& R. Chandiramani (eds.).

McGrath, I. (2004). "The representation of people in educational materials" in RELC,35(3), pp. 351-358.

Misra, G. \& R. Chandiramani (eds.). (2005). Sexuality, gender and rights: Exploring theory and practice in South and Southeast Asia. New Delhi, Thousand Oaks, London: Sage Publication.

Peterson, S.B. \& M.A. Lach. (1990). "Gender stereotypes in children's books: Their prevalence and influence on cognitive and affective development" in Gender and Education2(2): 185-197.

Stein, P. 2004. "Representation, rights, and resources: Multimodal pedagogies in the language and literacy classroom" in B. Norton and K. Toohey (eds.) Critical pedagogies and language learning. Cambridge: Cambridge University Press.

Sunderland, J. (ed.).(1994). Exploring gender: Questions and implications for English language education.

Hertfordshire: Prentice Hall International (UK) Ltd.

Sunderland, J., M. Cowley, F.A. Rahim, C. Leontzakou \& J. Shattuck. (2001).

"From bias 'In the text' to 'Teacher talk around the text' An exploration of teacher discourse and gendered foreign language textbook texts" in Linguistics and Education11(3), pp. 251-286

Toussidou, A. (2001). Political correctness in textbook dialogues: An investigation into male and female discourse roles. Unpublished MA Dissertation, University of Warwick, UK.

Wharton, S. 2005. "Invisible females, incapable males: Gender construction in children's reading scheme" in Language and Education 19(3), pp. 238-251.

Widdowson, H. G. (2003b). "Reply to Fairclough: Discourse and interpretation: conjectures and refutations" in B. Seidlhofer (ed.).Controversies in applied linguistics. Oxford: Oxford University Press.

Wodak, R. (ed.). (1997). Gender and discourse. London: Sage Publications. 
Damayanti, Gender construction in visual images in textbooks for....

Yuen, C. Y. (2004). "The construal of ideational meaning in print advertisements" in K.L. O'Hallloran (ed.).

Zimet, S.G. (1976). Print and prejudice. London: Hodder \& Stoughton Educational Ltd. 